\title{
Evaluation of IGFBP-7 DNA methylation changes and serum protein variation in Swedish subjects with and without type 2 diabetes
}

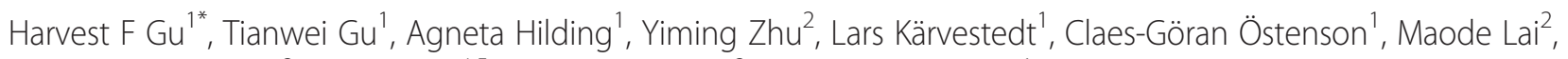
Masahiko Kutsukake ${ }^{3}$, Jan Frystyk ${ }^{4,5}$, Kazuhiro Tamura ${ }^{3}$ and Kerstin Brismar ${ }^{1}$

\begin{abstract}
Background: Insulin-like growth factor-binding protein 7 (IGFBP-7) is able to interact with insulin-like growth factor 1 (IGF-1) as well as insulin. Previous studies have suggested that serum IGFBP-7 levels may be associated with insulin resistance in type 2 diabetes (T2D). This study aimed to evaluate IGFBP-7 serum protein and IGFBP7 DNA methylation levels in the subjects with and without T2D.

Results: A total of 340 Swedish subjects including 100 newly diagnosed T2D patients (50 women/50 men), 100 age-matched nondiabetic control subjects (50/50) and 140 treated T2D patients (54/86) were studied. Serum IGFBP-7 levels were measured with a novel ELISA. IGF1, IGFBP-1, and insulin were determined by in-house radioimmunoassays. DNA methylation levels in the IGFBP7 gene were analyzed with a bisulfite-pyrosequencing technique. Serum IGFBP-7 protein levels were similar among nondiabetic subjects, newly diagnosed, and treated T2D patients and were not correlated with IGFBP7 DNA methylation. However, IGFBP7 DNA methylation was increased in men with newly diagnosed T2D compared with nondiabetic controls $(17.6 \%$ vs. $12.5 \%, P<0.01)$. Serum IGFBP-7 levels correlated $(r=0.331, P=0.019)$ with serum IGFBP-1 levels, a marker of insulin production, in men but not women with newly diagnosed T2D.

Conclusions: This study demonstrates for the first time that IGFBP7 DNA methylation levels are increased in Swedish men with newly diagnosed T2D. The correlation between IGFBP-7 and IGFBP-1 suggests that low IGFBP-7 may be associated with insulin resistance in T2D.
\end{abstract}

Keywords: IGF-1, IGFBP-1, IGFBP-7, Insulin, Type 2 diabetes

\section{Background}

Insulin-like growth factor 1 (IGF-1) is a polypeptide hormone, which shares structural homology and downstream signaling pathways with insulin. Several studies have demonstrated that IGF-1 has insulin-like effects, stimulating peripheral uptake of glucose and free fatty acids [1-3]. Low levels of serum IGF-1 are associated with an increasing risk of developing type 2 diabetes (T2D) and obesity $[4,5]$. IGF-1 circulates in blood predominantly complexed to specific IGF-binding proteins (IGFBP-1). There are six binding proteins (IGFBP-1 to 6) exhibiting high affinity to IGF-1 [1-3]. IGFBP-1 has

\footnotetext{
* Correspondence: harvest.gu@ki.se

${ }^{1}$ Rolf Luft Research Center for Diabetes and Endocrinology, Department of Molecular Medicine and Surgery, Karolinska Institutet, Karolinska University Hospital, Stockholm SE-171 76, Sweden

Full list of author information is available at the end of the article
}

been shown to prolong the half-life of IGF-1 and IGF-2. Elevations in insulin suppress the hepatic production of IGFBP-1, resulting in decreased circulating levels. Circulating IGFBP-1 levels are inversely correlated with 24-hour insulin secretion, insulin sensitivity, and an increased risk of cardiovascular diseases [6-9]. Finally, low IGFBP-1 levels may be permissive for the development of metabolic diseases, such as T2D, obesity, and related cardiovascular complications [10-13].

IGFBP-7 (also known as IGFBP-rP1, MAC25, PSF, TAF, FSTL2, or PGI2-stimulating factor) is an additional member of the IGFBP family. Unlike the high affinity of the other six IGFBPs, IGFBP-7 exhibits low affinity for IGF-1, but has a relatively high affinity for insulin $[14,15]$. It is hypothesized that IGFBP-7 may interfere with insulin action and subsequently play a role in the

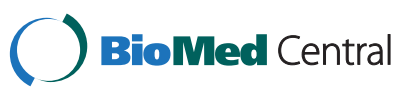


development of diabetes and diabetic vascular complication. There are three reports evaluating IGFBP-7 in T2D. In 2006, Lopez-Bermejo et al. [16] measured serum IGFBP-7 levels in 43 men with T2D and 113 nondiabetic subjects and found increased serum IGFBP-7 levels to be associated with insulin resistance. One year later, the same research group [17] detected serum IGFBP-7 levels in 24 male T2D patients with high-ferritin and suggested that vascular function was linked to serum IGFBP-7 levels in these patients. In 2008, Kutsukake et al. [18] developed a novel IGFBP-7 ELISA using two IGFBP-7 antibodies and analyzed serum IGFBP-7 levels in 33 male hemodialysis patients, including 18 patients with and 15 patients without T2D. Their data indicated that hemodialysis patients with T2D had higher serum IGFBP-7 levels than the hemodialysis patients without T2D.

These three studies suggested a possible association between IGFBP-7 and T2D. However, the sample sizes of T2D patients in the studies were relatively small and no female patient with T2D was included. Furthermore, recent studies have shown that epigenetic changes provide a link for the translation of environmental exposures into susceptibility for T2D. Epigenetic studies may provide useful information for a better understanding of the pathogenesis of T2D [19-21]. To our knowledge, no epigenetic study of the IGFBP7 gene in T2D has been reported. In this study, we have determined serum IGFBP-7 levels in a cohort consisting of 340 Swedish men and women including newly diagnosed T2D patients, agematched nondiabetic controls and anti-diabetic treated T2D patients. In addition, we analyzed levels of IGFBP7 DNA methylation. Our aims were to evaluate serum protein and DNA methylation levels of IGFBP-7 in T2D.

\section{Results}

Serum IGFBP-7 levels and correlation with IGFBP-1

Serum IGFBP-7 protein levels in both men and women with normal glucose tolerance (NGT), newly diagnosed T2D, and anti-diabetic treated T2D are presented in Table 1. No statistical significant difference in serum IGFBP-7 levels was found between the three groups, neither in analyses when data for men and women were combined nor in sex-specific analyses.

We then analyzed the correlations between serum IGFBP-7 protein levels and other laboratory variables, including fasting glucose, fasting insulin, homeostasis model of assessment insulin resistance (HOMA-IR), IGF-1, and IGFBP-1. In patients with newly diagnosed T2D, there was no correlation between IGFBP-7 and fasting glucose, fasting insulin, or HOMA-IR. However, a tendency towards a significant negative correlation was found between IGFBP-7 and IGF-1 $(r=-0.258, P=0.070)$ in men with newly diagnosed T2D (Table 2). Furthermore,
IGFBP-7 correlated positively with IGFBP-1 in these male patients $(r=0.331, P=0.019$, Figure 1$)$. Similar correlations were not observed in newly diagnosed women with newly diagnosed T2D. Apart from these correlations, none was observed.

\section{DNA methylation levels of the IGFBP7 gene}

To further investigate whether IGFBP-7 plays a role in T2D, we analyzed DNA methylation of the IGFBP7 gene in men with NGT or newly diagnosed T2D, respectively. Figure 2 demonstrates that IGFBP7 DNA methylation levels were significantly increased in newly diagnosed T2D patients compared with NGT subjects at all three CpG sites (P1: $10.4 \%$ vs. $6.2 \%$; P2: $14.3 \%$ vs. $8.6 \%$ and P3: $44.4 \%$ vs. $22.7 \%$, all $P<0.01)$. Combined data from all three $\mathrm{CpG}$ sites showed that genomic DNA methylation levels of the IGFBP7 gene in T2D were increased compared with subjects with NGT $(17.6 \%$ vs. $12.5 \%, P<0.01)$.

\section{Discussion}

We have determined serum IGFBP-7 levels in newly diagnosed T2D patients, age-matched nondiabetic controls and anti-diabetic treated T2D patients and for the first time found a correlation between IGFBP-7 and IGFBP-1 in men with newly diagnosed T2D. Moreover, we analyzed the levels of IGFBP7 DNA methylation and found that IGFBP7 DNA methylation levels were higher in male T2D patients than in nondiabetic subjects.

IGFBP-7 is widely expressed in various tissues, including the brain, lung, prostate, and gastrointestinal tract and the protein is also detectable in the circulation $[14,15]$. In this study, we measured serum IGFBP-7 protein levels using a novel sandwich ELISA protocol [18]. Data demonstrated that serum IGFBP-7 protein mean concentrations were 19 to $22 \mu \mathrm{g} / \mathrm{l}$ in Swedish men with and without T2D and 18.8 to $20.0 \mu \mathrm{g} / \mathrm{l}$ in women. Further, no statistically significant difference in serum IGFBP-7 protein levels was found between the subjects with NGT and newly diagnosed T2D or anti-diabetic treated T2D patients. Previously, Lopez-Bermejo et al. [16] reported that the mean levels of serum IGFBP-7 in Spanish men without and with T2D were 26 to $28 \mu \mathrm{g} / \mathrm{l}$ using an enzyme-linked immune-sorbent assay. Data in their study implicated that IGFBP-7 was associated with insulin resistance [16]. However, the association of IGFBP-7 with insulin resistance (determined as HOMAIR) was not observed in our study. The difference in results may be due to sample size and the selection criteria of the T2D patients. In this study, the sample size was larger and the patients were newly diagnosed, as compared with previous reports [16-18].

Low serum IGFBP-1 levels are found to be associated with hyperinsulinemia, insulin sensitivity, development of T2D, and obesity [10-12]. In this study, low serum 
Table 1 Clinical and laboratory variables in Swedish subjects with normal glucose tolerance and in the patients with type 2 diabetes

\begin{tabular}{|c|c|c|c|c|}
\hline & & \multicolumn{2}{|c|}{ Stockholm Diabetes Prevention Program } & \multirow{2}{*}{$\begin{array}{l}\text { Kronan } \\
\text { Type } 2 \text { diabetes }\end{array}$} \\
\hline & & $\begin{array}{l}\text { Normal glucose } \\
\text { tolerance }\end{array}$ & $\begin{array}{l}\text { Newly diagnosed type } 2 \\
\text { diabetes }\end{array}$ & \\
\hline$N=$ All (women/men) & & $100(50 / 50)$ & $100(50 / 50)$ & $140(54 / 86)$ \\
\hline \multirow[t]{3}{*}{ Age (years) } & All & $58(57$ to 58$)$ & 58 (57 to 58$)$ & $61(60 \text { to } 63)^{t+t \S \S \S}$ \\
\hline & Women & 57 (55 to 58$)$ & 57 (55 to 58$)$ & $62(60 \text { to } 64)^{\dagger+t \S \S \S}$ \\
\hline & Men & 58 (57 to 59$)$ & 58 (57 to 59 ) & $62(60 \text { to } 63)^{t+\S \S}$ \\
\hline \multirow[t]{3}{*}{ Body mass index $\left(\mathrm{kg} / \mathrm{m}^{2}\right)$} & All & 24.4 (23.8 to 25.1$)$ & $30.7(29.4 \text { to } 31.9)^{\dagger+\dagger}$ & $29.3(28.6 \text { to } 30.1)^{t+\dagger}$ \\
\hline & Women & 23.4 (22.7 to 24.1$)$ & $32.2(30.2 \text { to } 34.3)^{\dagger+t}$ & $29.7(28.4 \text { to } 30.9)^{\dagger+\dagger \S}$ \\
\hline & Men & $25.4(24.4 \text { to } 26.4)^{* * *}$ & $29.1(27.8 \text { to } 30.4)^{\dagger+\dagger *}$ & $29.1(28.1 \text { to } 30.2)^{t+\dagger}$ \\
\hline \multirow[t]{3}{*}{ Waist and hip ratio } & All & 0.86 (0.84 to 0.87$)$ & $0.93(0.92 \text { to } 0.94)^{t+t}$ & $0.95(0.94 \text { to } 0.96)^{\dagger+t \S}$ \\
\hline & Women & $0.82(0.80$ to 0.83$)$ & $0.90(0.88 \text { to } 0.91)^{\dagger+\dagger}$ & $0.90(0.89 \text { to } 0.92)^{t+t}$ \\
\hline & Men & $0.90(0.88 \text { to } 0.91)^{* * *}$ & $0.96(0.95 \text { to } 0.98)^{t++* * *}$ & $0.98(0.97 \text { to } 0.99)^{t+t * * *}$ \\
\hline \multirow[t]{3}{*}{ Systolic blood pressure (mm Hg) } & All & $130(127$ to 134$)$ & $146(143 \text { to } 150)^{\dagger+t}$ & $147(144 \text { to } 150)^{\dagger+\dagger}$ \\
\hline & Women & 129 (124 to 133$)$ & $147(141 \text { to } 152)^{t+\dagger}$ & $149(145 \text { to } 154)^{\dagger+\dagger}$ \\
\hline & Men & $132(126$ to 137$)$ & $146(141 \text { to } 150)^{\dagger+\dagger}$ & $146(142 \text { to } 150)^{\dagger+\dagger}$ \\
\hline \multirow[t]{3}{*}{ Diastolic blood pressure $(\mathrm{mm} \mathrm{Hg})$} & All & 80 (78 to 82$)$ & $87(85 \text { to } 90)^{t+t}$ & $83(81 \text { to } 84)^{\S \S \S}$ \\
\hline & Women & 79 (77 to 82$)$ & $86(83 \text { to } 89)^{\dagger+}$ & $81(78 \text { to } 83)^{\S}$ \\
\hline & Men & 82 (79 to 84$)$ & $89(86 \text { to } 92)^{t+\dagger}$ & $84(82 \text { to } 86)^{\S}$ \\
\hline \multirow[t]{3}{*}{ Fasting glucose (mmol/l) } & All & $4.8(4.7$ to 4.9$)$ & $6.8(6.4 \text { to } 7.1)^{\text {tt† }}$ & $9.0(8.5 \text { to } 9.5)^{\dagger+t \S \S \S}$ \\
\hline & Women & $4.6(4.4$ to 4.7$)$ & $6.6(6.2 \text { to } 6.9)^{\dagger+t}$ & $9.2(8.4 \text { to } 9.9)^{t+t \S \S \S}$ \\
\hline & Men & $5.0(4.9 \text { to } 5.1)^{* * *}$ & $6.9(6.4 \text { to } 7.5)^{t+\dagger}$ & $8.9(8.2 \text { to } 9.5)^{\dagger+t \S \S \S}$ \\
\hline \multirow[t]{3}{*}{ Fasting insulin $\left(\mathrm{pmol} / \mathrm{l}^{\mathrm{a}}\right.$} & All & 73 (68 to 78 ) & $140(126 \text { to } 156)^{t+\dagger}$ & $135(124 \text { to } 147)^{\dagger+\dagger}$ \\
\hline & Women & 70 (64 to 76$)$ & $150(130 \text { to } 173)^{t+\dagger}$ & $138(123 \text { to } 154)^{t+\dagger}$ \\
\hline & Men & 77 (69 to 85) & $131(112 \text { to } 154)^{\dagger+t}$ & $133(118 \text { to } 150)^{\dagger+\dagger}$ \\
\hline \multirow{3}{*}{$\begin{array}{l}\text { Homeostasis model of assessment: insulin } \\
\text { resistance }^{a}\end{array}$} & All & 2.56 (2.37 to 2.78 ) & 6.86 (6.03 to 7.79$)$ & $8.53(7.66 \text { to } 9.50)^{t+t \S}$ \\
\hline & Women & 2.33 (2.11 to 2.59$)$ & 7.20 (6.09 to 8.52$)$ & $9.00(7.78 \text { to } 10.41)^{t+\dagger}$ \\
\hline & Men & $2.82(2.49 \text { to } 3.18)^{*}$ & $6.52(5.35$ to 7.96$)$ & $8.25(7.09 \text { to } 9.60)^{t+\dagger}$ \\
\hline \multirow[t]{3}{*}{ IGF-I $\left(\mu \mathrm{g} / \mathrm{I}^{\mathrm{a}}\right.$} & All & $156(147$ to 167$)$ & 154 (144 to 165$)$ & $117(107 \text { to } 128)^{t+t \S \S \S}$ \\
\hline & Women & 154 (141 to 167$)$ & 157 (143 to 172) & $122(106 \text { to } 141)^{t \S \S}$ \\
\hline & Men & 159 (145 to 175$)$ & 152 (138 to 167$)$ & $114(102 \text { to } 128)^{t+t \S \S \S}$ \\
\hline \multirow[t]{3}{*}{ IGFBP-1 $(\mu \mathrm{g} /)^{\mathrm{a}}$} & All & 42 (38 to 47$)$ & $23(20 \text { to } 26)^{\dagger+t}$ & $17(14 \text { to } 20)^{t+t \S \S}$ \\
\hline & Women & 57 (50 to 65) & $28(24 \text { to } 33)^{+t \dagger}$ & $18(14 \text { to } 22)^{t+t \S \S}$ \\
\hline & Men & $31(27 \text { to } 37)^{* * *}$ & $19(16 \text { to } 23)^{t+* *}$ & $16(13 \text { to } 20)^{t+\dagger}$ \\
\hline \multirow[t]{3}{*}{ IGFBP-7 $\left(\mu \mathrm{g} / \mathrm{I}^{\mathrm{a}}\right.$} & All & 20.5 (18.7 to 22.3 ) & 19.6 (17.8 to 21.5$)$ & 19.2 (17.9 to 20.6$)$ \\
\hline & Women & 19.0 (16.8 to 21.4$)$ & 20.0 (17.0 to 23.5$)$ & 18.8 (16.7 to 21.7 ) \\
\hline & Men & 22.1 (19.4 to 25.1 ) & 19.2 (17.3 to 21.3$)$ & 19.5 (17.8 to 21.3$)$ \\
\hline
\end{tabular}

Data were expressed as means (95\% confidence interval $(\mathrm{Cl}))$ for normally distributed variables and as geometric means $(95 \% \mathrm{Cl})$ for ${ }^{\text {a }}$ non-normally distributed variables; Comparison between the three groups was performed by one-way analysis of variance (ANOVA), and if significant followed by Tukey's post-hoc test; ${ }^{\dagger} P<0.05,{ }^{+\dagger} p<0.01,{ }^{++\dagger} P<0.001$ vs. Stockholm Diabetes Prevention Program NGT and ${ }^{\S} P<0.05,{ }^{\S \S} P<0.01,{ }^{\S \S \S} p<0.001$ vs. Stockholm Diabetes Prevention Program type 2 diabetes; Comparison of men and women within groups was performed by unpaired $t$ test; ${ }^{*} P<0.05$, ${ }^{* *} P<0.01$, ${ }^{* * *} P<0.001$.

IGFBP-7 levels correlated with low serum IGFBP-1 levels in men with newly diagnosed T2D. We acknowledge that this observation may not be causal. Nevertheless, we have a hypothesis that low IGFBP-7 levels may be related to increased insulin and consequently associated to insulin resistance. However, further mechanistic investigations are needed to test this hypothesis.

Several studies have demonstrated that increased DNA methylation levels of the IGFBP7 gene are associated with colorectal cancers and lung and prostate cancer. 
Table 2 Univariate correlations between IGFBP-7 and other laboratory variables in Swedish subjects with normal glucose tolerance and newly diagnosed type 2 diabetes

\begin{tabular}{|c|c|c|c|c|c|c|}
\hline & \multicolumn{3}{|c|}{ Normal glucose tolerance } & \multicolumn{3}{|c|}{ Newly diagnosed type 2 diabetes } \\
\hline & All & Women & Men & All & Women & Men \\
\hline & $n=100$ & $n=50$ & $n=50$ & $n=100$ & $n=50$ & $n=50$ \\
\hline \multirow[t]{2}{*}{ Fasting glucose } & $r=0.016$ & $r=-0.158$ & $r=0.042$ & $r=0.016$ & $r=-0.158$ & $r=0.042$ \\
\hline & $P=0.877$ & $P=0.273$ & $P=0.771$ & $P=0.877$ & $P=0.273$ & $P=0.771$ \\
\hline \multirow[t]{2}{*}{ Fasting insulin ${ }^{a}$} & $r=0.080$ & $r=0.115$ & $r=0.013$ & $r=0.039$ & $r=0.136$ & $r=-0.107$ \\
\hline & $P=0.432$ & $P=0.427$ & $P=0.929$ & $P=0.702$ & $P=0.348$ & $P=0.462$ \\
\hline \multirow[t]{2}{*}{ HOMA-IR ${ }^{a}$} & $r=0.068$ & $r=0.047$ & $r=0.016$ & $r=0.012$ & $r=0.137$ & $r=-0.158$ \\
\hline & $P=0.499$ & $P=0.745$ & $P=0.914$ & $P=0.904$ & $P=0.344$ & $P=0.273$ \\
\hline \multirow[t]{2}{*}{$|G F-|^{a}$} & $r=0.053$ & $r=0.102$ & $r=-0.004$ & $r=-0.144$ & $r=-0.080$ & $r=-0.258$ \\
\hline & $P=0.599$ & $P=0.480$ & $P=0.977$ & $P=0.153$ & $P=0.583$ & $P=0.070$ \\
\hline \multirow[t]{2}{*}{ IGFBP-1 ${ }^{a}$} & $r=0.003$ & $r=0.149$ & $r=0.075$ & $r=0.114$ & $r=-0.071$ & $r=0.331$ \\
\hline & $P=0.978$ & $P=0.301$ & $P=0.607$ & $P=0.261$ & $P=0.626$ & $P=0.019$ \\
\hline
\end{tabular}

aLog-transformed before analyses.

IGFBP-7 may play a tumor-suppressor role in carcinogenesis of these cancers, mainly through inactivation of its DNA methylation [22-25]. DNA methylation is involved in the regulation and expression of genes [26]. This epigenetic mechanism is believed to be a contributing factor to pathological conditions, such as T2D [19-21]. In this study, we have, for the first time, provided evidence that DNA methylation levels in the IGFBP7 gene are increased in Swedish men with newly diagnosed T2D. This finding implicates that IGFBP7 DNA methylation may be associated with early diagnosis of T2D. Generally, DNA methylation of cytosine residues in $\mathrm{CpG}$ di-nucleotides

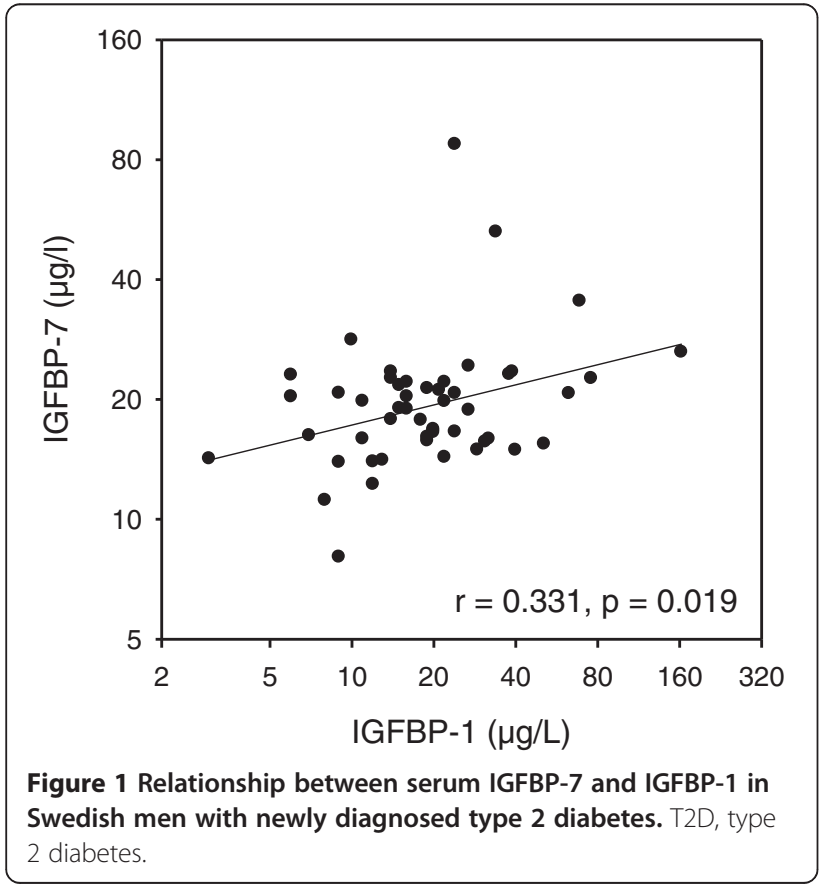

may lead to transcriptional silencing of the associated gene. In this study, we did not find any correlation between serum IGFBP-7 protein levels and IGFBP7 DNA methylation. One explanation is that DNA methylation may reduce gene transcription but not translation [26]. Furthermore, we have analyzed IGFBP7 DNA methylation levels in blood cells. However, we believe that investigations of tissue-specific IGFBP7 DNA methylation in T2D patients or diabetic animal models are necessary to better understand the correlation of IGFBP7 DNA methylation with serum IGFBP-7 protein levels.

Clinical observations in many populations, including Swedish cohorts, have shown that the prevalence and subsequent incidence of T2D are higher in men than in women $[27,28]$. The endogenous sex hormones may differentially modulate glycemic status and risk of T2D in men and women [29]. In this study, we found that IGFBP7 DNA methylation levels were associated with T2D in men but not in women. We do not know the mechanism of the sex-based difference in methylation $I G F B P 7$, but information from public genome databases implicates that the IGFBP7 mRNA expression levels are high in the prostate and testes but low in the breast and ovaries [30]. Furthermore, IGFBP-7 is known to be secreted by adipose tissues and, indeed, a sex-linked difference is seen in hormones secreted by adipocytes, such as adiponectin and leptin [31,32].

\section{Conclusions}

This study demonstrates for the first time that IGFBP7 DNA methylation is increased in Swedish men with newly diagnosed T2D compared with subjects with NGT. Low serum IGFBP-7 levels are related to low IGFBP-1 and subsequently associated with insulin resistance in T2D. 

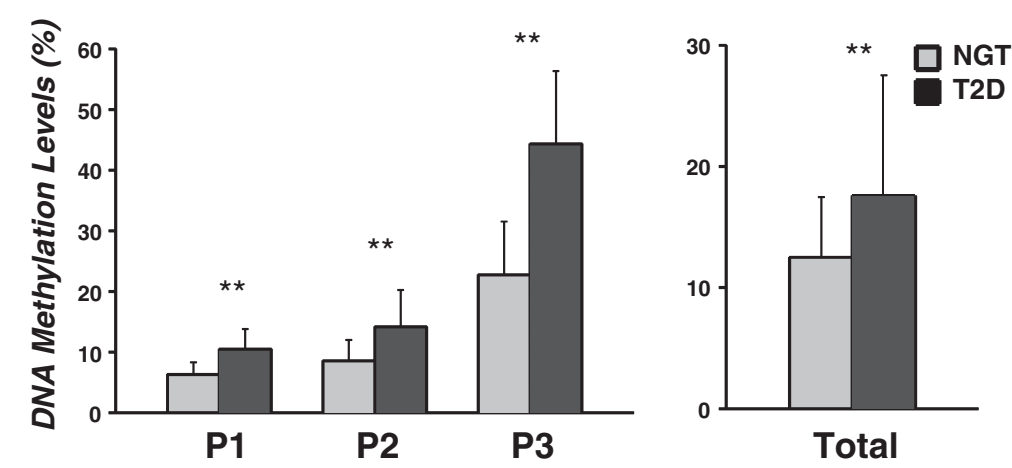

Figure 2 IGFBP7 DNA methylation levels in Swedish men with normal glucose tolerance and newly diagnosed type 2 diabetes. Data were mean \pm standard deviation. NGT, normal glucose tolerance; T2D, type 2 diabetes; ${ }^{* *} P<0.01$.

\section{Methods}

\section{Subjects}

A total of 340 subjects were selected from the Stockholm Diabetes Prevention Program (SDPP) and the Kronan study. All subjects were Swedish. In SDPP, men and women aged 35 to 56 years from five municipalities in the region of Stockholm, Sweden, were included in an epidemiological survey [33]. A follow-up study was performed after 10 and 8 years, respectively, in the SDPP and Kronan studies. Both baseline and follow-up studies consisted of a questionnaire covering lifestyle factors, a health examination and an oral glucose tolerance test. Based upon this test, all participants were categorized into glucose tolerance groups according to World Health Organization criteria [34]. For this study, 100 newly diagnosed T2D patients at the follow-up study, having either NGT or impaired glucose tolerance at baseline (50 women, 50 men), were selected. These T2D patients received no anti-diabetic medication when the blood samples were taken and the phenotypes recorded. One hundred nondiabetic controls (50 women, 50 men) were selected among those having NGT at both baseline and follow-up and matched to newly diagnosed T2D patients by sex and age. In the Kronan study, 140 patients with T2D (54 women, 86 men) were selected from three health care centers, Kronan, Hallonbergen, and Rissne, within the municipality of Sundbyberg, Stockholm, Sweden [35]. Patients with latent autoimmune diabetes of adults were excluded in this study. All patients received anti-diabetes treatment: $24 \%$ were treated with diet alone, $46 \%$ with oral hypoglycemic agents, $22 \%$ with insulin and $8 \%$ with a combination of insulin and oral hypoglycemic agents.

Informed consent from all participants was received. The study was approved by the Ethics Committee of Karolinska University Hospital, and was performed in accordance with the Declaration of Helsinki.

\section{DNA extraction and bisulfite treatment}

Genomic DNA was extracted from peripheral blood using the Gentra Puregene Blood Kit (Qiagen, Hilden, Germany). DNA samples were stored at $-80^{\circ} \mathrm{C}$ until use. For epigenetic analysis, bisulfite treatment of extracted DNA samples was done with the EpiTect Bisulfite Kit (Qiagen). This kit enables complete conversion of unmethylated cytosine to uracil and subsequent purification in less than 6 hours. This highly sensitive method utilizes innovative protection against DNA degradation and ensures high conversion rates of over $99 \%$. The experiments for DNA extraction and bisulfite treatment were conducted according to the manufacturer instruction.

\section{IGFBP7 methylation analyses}

The IGFBP7 gene is located in chromosome 4q12. In the IGFBP7 gene, there are three CpG sites (CGCTCGTGC CCACCTTGCTCGT, NT_022853.15) as indicated with the bold letter $\mathbf{C}$ and recorded as P1 to P3 (P for position). In a CpG site sequence, 5-methyl cytosine is followed by guanosine, which is the dominating type of methylation pattern in mammals. PyroMark CpG assay for the IGFBP7 gene methylation analysis (the detailed sequence information is recorded at ID: PM00112903, Qiagen) and PyroMark PCR kit (Qiagen) were used. Methylation levels of these CpG sites were detected using the PyroMark Gold 96 Reagent Kit (Qiagen) and the PyroMark Q96 ID Pyrosequencing System (Biotage, Uppsala, Sweden). Pyrosequencing methylation analysis of CpG sites is sensitive and accurate [36,37]. PyroQ-CpG software (Biotage) was used for methylation data analysis. Unmethylated bisulfite converted and unconverted DNA samples (Qiagen) were used for control of conversion efficiency of the bisulfite treatment and accuracy in methylation analyses.

\section{IGFBP-7 measurement}

IGFBP-7 levels in serum were measured using a novel sandwich ELISA, which incorporated a polyclonal and a 
monoclonal anti-IGFBP-7 antibody (R\&D Systems Inc., Abingdon, UK) as previously described [18]. Interassay and intra-assay coefficients of variation were $18.7 \%$ and $11.2 \%$, respectively. The average recovery rate was approximately $100 \%$. The sensitivity of the assay was $0.3 \mu \mathrm{g} / \mathrm{ml}$.

\section{Glucose, insulin, IGF-1, and IGFBP-1 measurements}

Fasting plasma glucose levels were analyzed in duplicate with a glucose oxidase analyzer (Yellow Springs, OH, USA). Fasting serum insulin levels were assayed by radioimmunoassay using our own antibodies, human insulin as a standard, and charcoal addition to separate antibody-bound and free insulin [38]. The same serum samples for measuring IGFBP-7 were used for measurement of IGF-1 and IGFBP-1. Measurement of IGF-1 in serum was performed after acid ethanol extraction and cryoprecipitation. Serum IGF-1 levels were determined by radioimmunoassay using des [1-3] IGF-1 as tracer. Intra-assay and interassay coefficients of variation were $4 \%$ and $11 \%$, respectively. Serum IGFBP1 levels were measured by an in-house radioimmunoassay with intraassay and interassay coefficients of variation of 3 and $10 \%$, respectively. The assay protocols have been described previously $[39,40]$.

\section{Statistical analysis}

Data are presented as means \pm standard deviation or as means with $95 \%$ CI for normally distributed variables. Non-normally distributed variables were log-transformed before analysis to normalize their distribution; their data are given as geometric means with $95 \%$ CI. Comparisons between independent groups were performed by unpaired $t$ test or by one-way ANOVA, followed by Tukey's posthoc test. Linear regression analysis was used to examine the relationship between variables. Homeostasis model of assessment was used to assess insulin resistance index (HOMA-IR) and calculated as:

(fasting serum glucose $\mathrm{mmol} / \mathrm{l} \times$ fasting serum insulin $\mathrm{mU} / \mathrm{l}) / 22.5$.

All statistical analyses were performed using Statistica, version 11 (StatSoft, Tulsa, OK, USA). A $P$ value of $<0.05$ was considered statistically significant.

\begin{abstract}
Abbreviations
ANOVA: Analysis of variance; Cl: Confidence interval; ELISA: Enzyme-linked immunosorbent assay; HOMA: Homeostasis model of assessment: IGF-1: Insulin-like growth factor 1; IGFBP-1: Insulin-like growth factor-binding protein 1; IGFBP-7: Insulin-like growth factor-binding protein 7; IR: Insulin resistance; NGT: Normal glucose tolerance; PCR: Polymerase chain reaction; SDPP: Stockholm Diabetes Prevention Program; T2D: Type 2 diabetes.
\end{abstract}

\section{Competing interest}

The authors declare that they have no competing interests.

\section{Authors' contributions}

HFG and KB designed the study; TG, HFG, MK, KT, YZ, ML, AH, LK, CGÖ, and JF collected experimental and clinical data; $\mathrm{AH}, \mathrm{TG}$, and $\mathrm{HFG}$ analyzed the data; HFG and KB wrote the manuscript. All authors contributed to data interpretation, discussion, and revision of the manuscript. All authors read and approved the final manuscript.

\section{Acknowledgements}

The authors wish to thank all subjects of the SDPP and Kronan studies for their participation in this study. This work was supported by the Family Erling-Persson Foundation, Swedish Research Council, Swedish Diabetes Foundation, Karolinska Foundation, Swedish Council for Working Life and Social Research, and Novo Nordisk Scandinavia.

\section{Author details}

'Rolf Luft Research Center for Diabetes and Endocrinology, Department of Molecular Medicine and Surgery, Karolinska Institutet, Karolinska University Hospital, Stockholm SE-171 76, Sweden. ${ }^{2}$ Department of Molecular

Pathology, School of Medicine, Zhejiang University, Hangzhou, PR China.

${ }^{3}$ Department of Endocrine Pharmacology, Tokyo University of Pharmacy and Life Sciences, Tokyo, Japan. ${ }^{4}$ Medical Research Laboratory, Department of Clinical Medicine, Faculty of Health, Aarhus University, Aarhus, Denmark. ${ }^{5}$ Department of Endocrinology and Internal Medicine, Aarhus University Hospital, Aarhus, Denmark.

Received: 4 July 2013 Accepted: 5 October 2013

Published: 4 November 2013

\section{References}

1. Laron Z: The GH-IGF1 axis and longevity. the paradigm of IGF1 deficiency. Hormones (Athens) 2008, 7(1):24-27.

2. LeRoith D, Yakar S: Mechanisms of disease: metabolic effects of growth hormone and insulin-like growth factor 1. Nat Clin Pract Endocrinol Metab 2007, 3(3):302-310

3. Clemmons DR: Modifying IGF1 activity: an approach to treat endocrine disorders, atherosclerosis and cancer. Nat Rev Drug Discov 2007, 6(10):821-833

4. Juul A: Serum levels of insulin-like growth factor I and its binding proteins in health and disease. Growth Horm IGF Res 2003, 13(4):113-170.

5. Dunger DB, Ong KK, Sandhu MS: Serum insulin-like growth factor-l levels and potential risk of type 2 diabetes. Horm Res 2003, 60(Suppl 3):131-135.

6. Brismar K, Fernqvist-Forbes E, Wahren J, Hall K: Effect of insulin on the hepatic production of insulin-like growth factor-binding protein-1 (IGFBP-1), IGFBP-3, and IGF-I in insulin-dependent diabetes. J Clin Endocrinol Metab 1994, 79(3):872-878

7. Brismar K, Grill V, Efendic S, Hall K: The insulin-like growth factor binding protein-1 in low and high insulin responders before and during dexamethasone treatment. Metabolism 1991, 40(7):728-732.

8. Hilding A, Brismar K, Degerblad M, Thorén M, Hall K: Altered relation between circulating levels of insulin-like growth factor-binding protein-1 and insulin in growth hormone-deficient patients and insulin-dependent diabetic patients compared to that in healthy subjects. $J$ Clin Endocrinol Metab 1995, 80(9):2646-2652.

9. Domené HM, Hwa V, Argente J, Wit JM, Camacho-Hübner C, Jasper HG, Pozo J, van Duyvenvoorde HA, Yakar S, Fofanova-Gambetti OV, Rosenfeld RG, ALS International Collaborative Group: Human acid-labile subunit deficiency: clinical, endocrine and metabolic consequences. Horm Res 2009, 72(3):129-141

10. Lewitt MS, Hall K, Bang P, Brismar K: Altered response of insulin-like growth factor-binding protein 1 to nutritional deprivation in type 2 diabetes mellitus. Metabolism 2005, 54(3):275-280.

11. Lewitt MS, Hilding A, Ostenson CG, Efendic S, Brismar K, Hall K: Insulin-like growth factor-binding protein-1 in the prediction and development of type 2 diabetes in middle-aged Swedish men. Diabetologia 2008, 51 (7):1135-1145.

12. Petersson U, Ostgren CJ, Brudin L, Brismar K, Nilsson PM: Low levels of insulin-like growth-factor-binding protein-1 (IGFBP-1) are prospectively associated with the incidence of type 2 diabetes and impaired glucose tolerance (IGT): the Söderåkra Cardiovascular Risk Factor Study. Diabetes Metab 2009, 35(3):198-205.

13. Rajwani A, Ezzat V, Smith J, Yuldasheva NY, Duncan ER, Gage M, Cubbon RM, Kahn MB, Imrie H, Abbas A, Viswambharan H, Aziz A, Sukumar P, VidalPuig A, Sethi JK, Xuan S, Shah AM, Grant PJ, Porter KE, Kearney MT, Wheatcroft SB: Increasing circulating IGFBP1 levels improves insulin sensitivity, 
promotes nitric oxide production, lowers blood pressure, and protects against atherosclerosis. Diabetes 2012, 61(4):915-924.

14. Oh Y, Nagalla SR, Yamanaka Y, Kim HS, Wilson E, Rosenfeld RG: Synthesis and characterization of insulin-like growth factor-binding protein (IGFBP)-7. Recombinant human mac25 protein specifically binds IGF-I and -II. J Biol Chem 1996, 271(48):30322-30325.

15. Yamanaka $Y$, Wilson EM, Rosenfeld RG, Oh Y: Inhibition of insulin receptor activation by insulin-like growth factor binding proteins. J Biol Chem 1997, 272(49):30729-30734.

16. López-Bermejo A, Khosravi J, Fernández-Real JM, Hwa V, Pratt KL, Casamitjana R, Garcia-Gil MM, Rosenfeld RG, Ricart W: Insulin resistance is associated with increased serum concentration of IGF-binding proteinrelated protein 1 (IGFBP-rP1/MAC25). Diabetes 2006, 55(8):2333-2339.

17. López-Bermejo A, Khosravi J, Ricart W, Castro A, Hwa V, Pratt KL, Casamitjana R, Rosenfeld RG, Fernández-Real JM: Insulin-like growth factor binding protein-related protein 1 (IGFBP-rP1/MAC25) is linked to endothelial-dependent vasodilation in high-ferritin type 2 diabetes. Diabetes Care 2007, 30(6):1615-1617.

18. Kutsukake M, Ishihara R, Momose K, Isaka K, Itokazu O, Higuma C, Matsutani T, Matsuda A, Sasajima K, Hara T, Tamura K: Circulating IGF-binding protein 7 (IGFBP7) levels are elevated in patients with endometriosis or undergoing diabetic hemodialysis. Reprod Biol Endocrinol 2008, 6:54.

19. Ling C, Groop L: Epigenetics: a molecular link between environmental factors and type 2 diabetes. Diabetes 2009, 58(12):2718-2725.

20. Gilbert ER, Liu D: Epigenetics: the missing link to understanding $\beta$-cell dysfunction in the pathogenesis of type 2 diabetes. Epigenetics 2012, 7 (8):841-852

21. Drong AW, Lindgren CM, McCarthy Ml: The genetic and epigenetic basis of type 2 diabetes and obesity. Clin Pharmacol Ther 2012, 92(6):707-715.

22. Ruan W, Xu E, Xu F, Ma Y, Deng H, Huang Q, Lv B, Hu H, Lin J, Cui J, Di M, Dong J, Lai M: IGFBP7 plays a potential tumor suppressor role in colorectal carcinogenesis. Cancer Biol Ther 2007, 6(3):354-359.

23. Dimberg J, Hong T, Skarstedt M, Löfgren S, Zar N, Matussek A: Analysis of APC and IGFBP7 promoter gene methylation in Swedish and Vietnamese colorectal cancer patients. Oncol Lett 2013, 5(1):25-30.

24. Sullivan L, Murphy TM, Barrett C, Loftus B, Thornhill J, Lawler M, Hollywood D, Lynch T, Perry AS: IGFBP7 promoter methylation and gene expression analysis in prostate cancer. J Urol 2012, 188(4):1354-1360.

25. Suzuki M, Shiraishi K, Eguchi A, Ikeda K, Mori T, Yoshimoto K, Ohba Y, Yamada T, Ito T, Baba Y, Baba H: Aberrant methylation of LINE-1, SLIT2, MAL and IGFBP7 in non-small cell lung cancer. Oncol Rep 2013, 29 (4):1308-1314

26. Chiacchiera F, Piunti A, Pasini D: Epigenetic methylations and their connections with metabolism. Cell Mol Life Sci 2013, 70(9):1495-1508.

27. Almdal T, Scharling $H$, Jensen JS, Vestergaard $H$ : Higher prevalence of risk factors for type 2 diabetes mellitus and subsequent higher incidence in men. Eur J Intern Med 2008, J19(1):40-45.

28. Gudbjörnsdottir S, Cederholm J, Nilsson PM, Eliasson B, Steering Committee of the Swedish National Diabetes Register: The national diabetes register in Sweden: an implementation of the St. Vincent declaration for quality improvement in diabetes care. Diabetes Care 2003, 26(4):1270-1276.

29. Ding EL, Song Y, Malik VS, Liu S: Sex differences of endogenous sex hormones and risk of type 2 diabetes: a systematic review and metaanalysis. JAMA 2006, 295(11):1288-1299.

30. Insulin-Like Growth Factor Binding Protein 7. http://www.genecards.org/cgibin/carddisp.pl?gene=|GFBP7\&search=|GFBP7.

31. Ziemke F, Mantzoros CS: Adiponectin in insulin resistance: lessons from translational research. Am J Clin Nutr 2010, 91(1):258S-261S.

32. Wauters M, Van Gaal L: Gender differences in leptin levels and physiology: a role for leptin in human reproduction. J Gend Specif Med 1999, 2(5):46-51.

33. Eriksson AK, Ekbom A, Granath F, Hilding A, Efendic S, Ostenson CG: Psychological distress and risk of pre-diabetes and type 2 diabetes in a prospective study of Swedish middle-aged men and women. Diabet Med 2008, 25(7):834-842.

34. Alberti K, Zimmet P: Definition, diagnosis and classification of diabetes mellitus and its complications. Part 1: diagnosis and classification of diabetes mellitus provisional report of a WHO consultation. Diabet Med 1998, 15:539.

35. Romelsjö A, Haglund BJ, Diderichsen F, Hallqvist J, Holland S, Nordström G, Svanström L: Participation of primary health care personnel in the
Stockholm Health of the Population Study - a preliminary report. Scand J Prim Health Care Suppl 1988, 1:97-103.

36. Tost J, Dunker J, Gut IG: Analysis and quantification of multiple methylation variable positions in CpG islands by pyrosequencing. Biotechniques 2003, 35(1):152-156.

37. Colella S, Shen L, Baggerly KA, Issa JP, Krahe R: Sensitive and quantitative universal Pyrosequencing methylation analysis of $\mathrm{CpG}$ sites. Biotechniques 2003, 35(1):146-150.

38. Herbert V, Lau KS, Gottlieb CW, Bleicher SJ: Coated charcoal immunoassay of insulin. J Clin Endocrinol Metab 1965, 25(10):1375-1384.

39. Bang P, Eriksson U, Sara V, Wivall IL, Hall K: Comparison of acid ethanol extraction and acid gel filtration prior to IGF-I and IGF-II radioimmunoassays: improvement of determinations in acid ethanol extracts by the use of truncated IGF-I as radioligand. Acta Endocrinol (Copenh) 1991, 124 (6):620-629.

40. Póvoa G, Roovete A, Hall K: Cross-reaction of serum somatomedinbinding protein in a radioimmunoassay developed for somatomedinbinding protein isolated from human amniotic fluid. Acta Endocrinol (Copenh) 1984, 107(4):563-570.

doi:10.1186/1868-7083-5-20

Cite this article as: Gu et al:: Evaluation of IGFBP-7 DNA methylation changes and serum protein variation in Swedish subjects with and without type 2 diabetes. Clinical Epigenetics 2013 5:20.

\section{Submit your next manuscript to BioMed Central and take full advantage of:}

- Convenient online submission

- Thorough peer review

- No space constraints or color figure charges

- Immediate publication on acceptance

- Inclusion in PubMed, CAS, Scopus and Google Scholar

- Research which is freely available for redistribution
C) Biomed Central 